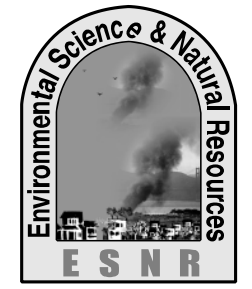

\title{
Effect of Water Quality, Environmental Sanitation and Hygiene Practices on Health of School Going Children of Urban Slum Areas
}

\author{
M. A. Haque ${ }^{1}$, M. N. Haque ${ }^{1 *}$, M. M. Sultana ${ }^{2}$, S. M. Hossen ${ }^{3}$ and S. Paul ${ }^{4}$ \\ ${ }^{1}$ Department of Food Technology and Nutritional Science, ${ }^{3}$ Department of Statistics \\ Mawlana Bhashani Science and Technology University, Santosh, Tangail-1902 \\ ${ }^{2}$ Vrije Universiteit Brussel (VUB), Brussels, Belgium \\ ${ }^{4}$ Human Rights Unit, Concern Universal, Bangladesh \\ *Corresponding author: nezamul.mbstu@gmail.com
}

\begin{abstract}
The study was carried out among the 246 school going children of urban slum of Tangail district and random sampling methods were applied. Slum population has been increasing in Bangladesh over the last three decades along with the growth and expansion of cities and towns. The facilities in urban slums were very much unsatisfactory due to lack of proper water supply and adequate hygiene and sanitation facilities. The good hygienic and sanitation knowledge and the practice have been found to be significantly low among the slum dwellers of Tangail district. Thewater supply and sanitation condition are improving very slowly in the urban slums of Tangail. Majority (94.7\%) of the slum people use tube well water for drinking, cleaning and household purposes. The dustbin facility was the most neglected sector in these slums. Besides, Solid waste management and drainage system were totally unsatisfactory. It was observed that houses, shops, drains, roads etc. have been constructed unplanned and solid wastes were preserved on open places. Majority $(58.1 \%)$ of the children did not ware sandal while going to latrine and did not cut finger nail regularly (54.5\%). Most of the slum dwellers (63.4\%) did not use cover for safety of the prepared food. It was observed that there was presence of pet/animal/insect in food preparation area of maximum households. Most of the people were unaware about toilet cleaning regularly. Findings of the study showed that $40.7 \%$ children were underweight, $28.9 \%$ children were stunted and $31.3 \%$ children were wasted. The child morbidity rate was high. Water quality, environmental sanitation and hygiene practices were positively correlated $(r=0$ to +1$)$ with health status of school going children. Thewater quality, environmental sanitation and hygiene practices have significant impact $(\mathrm{p} \leq$ 0.05 ) on the health of school going children of these slums.
\end{abstract}

Key words: Environmental sanitation, Hygiene, Health status, Water quality

\section{Introduction}

In the words of the $35^{\text {th }}$ president of the United States, John F. Kennedy, "Children are the world's most valuable resource and its best hope for the future." It is undeniably true that the future is in the hands of the children. Hence, the health and wellbeing of children go a long way in nurturing them into better adults (Rema and Vasanthamani, 2011).Children are the most important assets of a country because they will be tomorrow's youth and provide the human potential required for its development. Nutrition in the early years of life plays a big role in physical, mental and emotional development (Biswas et al., 2009). Malnutrition is one of the principle public health problems that affect large numbers of children in developing countries. School children may also be at high nutritional risk, not only under-five children. The school age is a dynamic period of growth and development. During this period physical, mental, social development of child takes place (Singh and West, 2004). Poor health and malnutrition may impair both the growth and cognitive development of primary school children. School children are dramatically affected by anemia (Hasan et al., 2013), vitamin A deficiency (Brooker et al., 2006) and parasitic infections (Awasthi and Bundy, 2007) with adverse impact on their nutritional status (Awasthi and Bundy, 2007; Casapia et al., 2006) as well as on their cognitive development and school performance also (Ong et al., 1991; Pollitt, 1999; Singh, 2004; Florence et al., 2008).The major portion of these excreta is deposited into water bodies and open places which pollute water sources, groundwater and the general environment. As a result, majority of the population in Bangladesh suffer from different kinds of water and excreta-borne diseases that aggravate their poverty situations. The global health burden associated with these conditions is staggering, with an estimated 4000-6000 children dying each day from diseases associated with lack of access to safe drinking water, inadequate sanitation and poor hygiene(Moe and Rheingans, 2006). High levels of stunting among children suggest that there was also a long term deficit in mental and physical development that leaves children unable to take maximum advantage of learning opportunities in schools. Epidemiological evidences suggest a strong link between maternal and early childhood under nutrition and increased adult risk of various chronic diseases (UNICEF, 2000).

\section{Materials and Methods}

\section{Study design}

This cross-sectional descriptive study of Effect of Water Quality, Environmental Sanitation and Food Hygiene Practices on Health of school-age slum children 5 to 12 years old, took place between October 2014 and March 2015 in urban slums of Tangail Pourashava. 


\section{Study area}

The study area includes Horizon polli, Robidas para, Mishuk mohollah, Rotary polli slum of Tangail pourashava.

\section{Study population}

Pre-school and school going children of the selected slums were the population of this study.

\section{Sample size and sampling technique}

Random sampling method was adopted to conduct this study. A total of 246 (123 boys and 123 girls) children were assigned randomly to collect data. 246 children and their mothers were interviewed.

\section{Data collection tools and techniques}

A pre-designed and pre-tested questionnaire was used to interview the study participants to elicit information on socioeconomic condition, water quality,environmental sanitation, hygiene practices, and anthropometric measurements like weight, height, MUAC and physical fitness of school going children.

\section{Anthropometric measurement}

The anthropometric data were collected based on standard methods. The age of the children was collected from the school record as well as respondents itself or from the mother of the children. Weight was recorded in kilograms by using standard weighting machine. Height was recorded in centimeter by using standard height measurement scale. Height was measured to the nearest $0.1 \mathrm{~cm}$.

\section{Assessment of nutritional status}

The nutritional status of school children was assessed by anthropometric measurements, age in year, height in centimeter $(\mathrm{cm})$ and weight in kilograms (kg). It was determined by $\mathrm{Z}$-score value.

\section{Assessment of hygienic condition}

Some basic hygiene practice related questionswere asked for the assessment of hygienic condition.

\section{Assessment of environmental sanitation}

Some Environmental sanitation related questions were askedfor the assessment of environmental sanitation condition.

\section{Assessment of water quality}

Some basic water quality related questions were asked for the assessment of water quality.

\section{Morbidity pattern}

Morbidity pattern was assessed by the presence of illness during the study period and any disease that had occurred since the last one year.

\section{Data analysis}

All of the statistical analysis and all other data processing were done by using SPSS 16.0 windows program. For tabular, charts and graphical presentation Microsoft Word and Microsoft Excel was used.

\section{Study period}

October, 2014 to March, 2015

\section{Results and Discussion}

Table 1. Level of education of the children

\begin{tabular}{|c|c|c|c|}
\hline \multirow{2}{*}{$\begin{array}{c}\text { Level of } \\
\text { education }\end{array}$} & \multicolumn{2}{|c|}{ Gender } & \multirow{2}{*}{ Total } \\
\cline { 2 - 3 } & Boys & Girls & \\
\cline { 2 - 3 } & $\begin{array}{c}\text { Frequency } \\
(\%)\end{array}$ & $\begin{array}{c}\text { Frequency } \\
(\%)\end{array}$ & $\begin{array}{c}\text { Frequency } \\
(\%)\end{array}$ \\
\hline Pre-primary & $35(28.5 \%)$ & $29(23.6 \%)$ & $64(26.0 \%)$ \\
\hline Primary & $88(71.5 \%)$ & $94(76.4 \%)$ & $182(74.0 \%)$ \\
\hline Total & $123(100.0 \%)$ & $123(100.0 \%)$ & $246(100.0 \%)$ \\
\hline
\end{tabular}

Table 1 shows the total of $26.0 \%$ child respondents were pre-primary student and $74.0 \%$ children respondents were primary student. It was observed that $28.5 \%$ of boys and $23.6 \%$ of girls were preprimary student, $71.5 \%$ of boys and $76.4 \%$ of girls were primary student.

Table 2. Water sources for drinking, cleaning utensils and household purposes

\begin{tabular}{|c|c|c|}
\hline $\begin{array}{l}\text { Water source for drinking, } \\
\text { cleaning utensils and household } \\
\text { purposes }\end{array}$ & Frequency & $\%$ \\
\hline Tube well & 233 & 94.7 \\
\hline Supply water by Tap & 13 & 5.3 \\
\hline Total & $\mathbf{2 4 6}$ & $\mathbf{1 0 0}$ \\
\hline
\end{tabular}

Table 2 shows that maximum $(94.7 \%)$ households of the slum used tube-well water for drinking, cleaning utensils and household purposes. Only 5.3 $\%$ households of the slum used supply water by Tap for drinking, cleaning utensils and household purposes.

Table 3. Purification of water before drinking

\begin{tabular}{|c|c|c|}
\hline $\begin{array}{c}\text { Purification of water } \\
\text { before drinking }\end{array}$ & Frequency & \% \\
\hline Yes & 0 & 0 \\
\hline No & 246 & 100.0 \\
\hline Total & $\mathbf{2 4 6}$ & $\mathbf{1 0 0}$ \\
\hline
\end{tabular}

Table 3 shows that the entire (100\%) household didn't purify water before drinking. They drink water directly from tube well or supply water by Tap without any purification. Economic problem is another barrier; they are not interested to buy water purification tools due to their economic problems.

Table 4. Appearance of drinking water

\begin{tabular}{|c|c|c|}
\hline $\begin{array}{c}\text { Appearance of drinking } \\
\text { water }\end{array}$ & Frequency & $\%$ \\
\hline Clean & 40 & 16.3 \\
\hline Ironic (looks yellow) & 185 & 75.2 \\
\hline Presence of odor & 21 & 8.5 \\
\hline Total & 246 & 100 \\
\hline
\end{tabular}

Table 4 shows that the appearance of maximum household's drinking water was Ironic (yellow color), $16.3 \%$ household drinking water was clean and $8.5 \%$ had presence of odor. There is no deep tube well facility in these slum areas. Ironic water is a main problem for using drinking and domestic purposes. 
Table 5. Frequency of toilet cleaning

\begin{tabular}{|l|c|c|}
\hline $\begin{array}{l}\text { Frequency toilet } \\
\text { cleaning }\end{array}$ & Frequency & \% \\
\hline One day per week & 61 & 24.8 \\
\hline Two day per week & 9 & 3.7 \\
\hline Three day per week & 49 & 19.9 \\
\hline Not aware & 127 & 51.6 \\
\hline Total & $\mathbf{2 4 6}$ & $\mathbf{1 0 0 . 0}$ \\
\hline
\end{tabular}

Table 5 shows that most of the household members were unaware about toilet cleaning, $51.6 \%$ toilets werenot cleaned regularly, $24.8 \%$ toilets were cleaned one day per week and $19.9 \%$ toilets were cleaned three day per week. Most of the slum dwellers has no complete knowledge about the importance of cleanliness and sanitation on health for that reason they are not completely aware about toilet cleaning.

Table 6. Way to dispose solid waste

\begin{tabular}{|l|c|c|}
\hline $\begin{array}{l}\text { Way to dispose solid } \\
\text { waste }\end{array}$ & Frequency & $\%$ \\
\hline $\begin{array}{l}\text { Thrown outside the } \\
\text { house }\end{array}$ & 42 & 17.1 \\
\hline Thrown in dustbin & 23 & 9.3 \\
\hline Thrown in drain/canal & 26 & 10.6 \\
\hline Preserve in open space & 155 & 63.0 \\
\hline Total & 246 & 100.0 \\
\hline
\end{tabular}

Table 6 shows that $63 \%$ households were preserve their solid waste in open space, $17.1 \%$ and $10.6 \%$ households were thrown their solid waste outside the house and drain/canal respectively. Only $9.3 \%$ households were thrown in dustbin. Due to unawareness and lack of dustbin facilities most of the slum people preserve their solid waste in open space or thrown into drain/ canal or outside the house.

Table 7. Wearing sandal while going to latrine

\begin{tabular}{|c|c|c|}
\hline $\begin{array}{c}\text { Ware sandal while } \\
\text { going to latrine }\end{array}$ & Frequency & $\%$ \\
\hline Yes & 103 & 41.9 \\
\hline No & 143 & 58.1 \\
\hline Total & 246 & 100.0 \\
\hline
\end{tabular}

Table 7 shows that maximum children $(58.1 \%)$ didn't not ware sandal while going to latrine, $41.9 \%$ children ware sandal while going to latrine. In the slum parents don't properly care their children, children are unaware about hygiene and sanitation information and don't interested to maintain hygiene and sanitation.

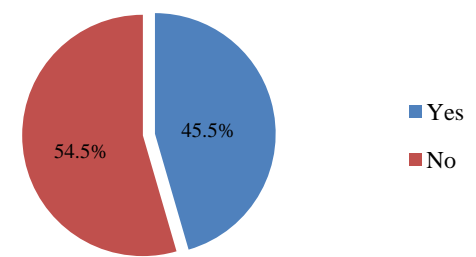

Fig. 1. Cut finger nail regularly
Fig. 1 shows that majority $(54.5 \%)$ of the children didn't not cut finger nail regularly, $45.5 \%$ children cut their finger nail regularly.

Table 8. Use covers for safety of the prepared food

\begin{tabular}{|c|c|c|}
\hline $\begin{array}{c}\text { Use cover for safety } \\
\text { of the prepared food }\end{array}$ & Frequency & $\boldsymbol{\%}$ \\
\hline Yes & 90 & 36.6 \\
\hline No & 156 & 63.4 \\
\hline Total & 246 & 100.0 \\
\hline
\end{tabular}

Table 8 shows that most of the $(63.4 \%)$ household didn't not use cover for safety of the prepared food, $36.6 \%$ use cover properly for safety of the prepared food. Lack of proper knowledge about food safety is the main reason of unawareness about food safety.

Table 9. Presence of pet/animal/insect in food preparation area

\begin{tabular}{|c|c|c|}
\hline $\begin{array}{c}\text { Presence of } \\
\text { pet/animal/insect in food } \\
\text { preparation area }\end{array}$ & Frequency & $\%$ \\
\hline Yes & 194 & 78.9 \\
\hline No & 52 & 21.1 \\
\hline Total & 246 & 100.0 \\
\hline
\end{tabular}

Table 9 shows that pet/animal/insect were present in food preparation area of maximum households (78.9), only in $21.1 \%$ households there is no presence of pet/animal/insect in food preparation area.

Table 10. Frequency of drain/sewage lines cleaning

\begin{tabular}{|c|c|c|}
\hline $\begin{array}{c}\text { Frequency of drain/sewage } \\
\text { lines cleaning }\end{array}$ & Frequency & $\%$ \\
\hline Rarely cleaned up & 155 & 63.0 \\
\hline No drainage facility & 91 & 37.0 \\
\hline Total & 246 & 100.0 \\
\hline
\end{tabular}

Table 10 shows that majority $(63 \%)$ of the drain/sewage lines in the slum were rarely cleaned up $37 \%$ households have no drainage facility. The Pourashava cleaner do not regularly clean the drain/sewage line.

Table 11. Frequency of removing waste from the dustbin

\begin{tabular}{|c|c|c|}
\hline $\begin{array}{c}\text { Frequency of removing } \\
\text { waste from the dustbin }\end{array}$ & Frequency & \% \\
\hline Rarely remove & 31 & 12.6 \\
\hline No dustbin near the slum & 215 & 87.4 \\
\hline Total & 246 & 100.0 \\
\hline
\end{tabular}

Table 11 shows that only $12.6 \%$ dustbin waste removed rarely, most of the households have no dustbin facility. The Pourashava cleaner do not regularly remove waste from dustbin. 
Table 12. Morbidity profile of school going children $(n=246)$

\begin{tabular}{|l|c|c|c|}
\hline \multicolumn{1}{|c|}{ *Disease } & Boysn (\%) & Girlsn(\%) & Totaln(\%) \\
\hline Diarrhea & $30(24.4)$ & $24(19.5)$ & $54(21.9)$ \\
\hline Dycenty & $20(16.3)$ & $14(11.4)$ & $34(13.8)$ \\
\hline Cold cough & $122(99.2)$ & $122(99.2)$ & $244(99.2)$ \\
\hline Fever & $41(33.3)$ & $34(27.6)$ & $75(30.5)$ \\
\hline Worm & $26(21.1)$ & $28(22.6)$ & $54(21.9)$ \\
\hline Jaundice & $3(2.4)$ & $4(3.2)$ & $7(2.8)$ \\
\hline Oral cavity & $11(8.9)$ & $11(8.9)$ & $22(8.9)$ \\
\hline Eye infection & $3(2.4)$ & $3(2.4)$ & $6(2.4)$ \\
\hline Skin & $42(34.1)$ & $49(39.8)$ & $91(36.9)$ \\
\hline Ear infection & $16(13.0)$ & $20(16.3)$ & $36(14.6)$ \\
\hline Others & $90(73.2)$ & $81(65.8)$ & $171(69.5)$ \\
\hline
\end{tabular}

*Multiple Responses

Themorbidity rate was high. This was obtained by asking whether the child had fallen ill within the last one year. Table 12 indicates that $99.2 \%$ of the children suffered from cold, $36.9 \%$ from skin disease and $30.5 \%$ from fever, $21.9 \%$ suffered from diarrhea, $13.8 \%$ suffered from dycenty, $21.9 \%$ suffered from worm, $14.6 \%$ suffered from ear infection and $69.5 \%$ suffered from other diseases.

Table 13. Overall nutritional status of children $(\mathrm{n}=246)$

\begin{tabular}{|c|c|c|c|}
\hline $\begin{array}{c}\text { Nutritional } \\
\text { Status }\end{array}$ & WAZ & HAZ & WHZ \\
\hline $\begin{array}{c}\text { Under the } \\
\text { Normal }\end{array}$ & $\begin{array}{c}100 \\
(40.7 \%)\end{array}$ & $\begin{array}{c}71 \\
(28.9 \%)\end{array}$ & $\begin{array}{c}77 \\
(31.3 \%)\end{array}$ \\
\hline Normal & $145(58.9 \%)$ & $172(69.9 \%)$ & $164(66.7)$ \\
\hline Over the Normal & $1(0.4 \%)$ & $3(1.2 \%)$ & $5(2.0 \%)$ \\
\hline Total (100\%) & 246 & 246 & 246 \\
\hline
\end{tabular}

Table 13 shows that in case of Weight for Age (WAZ) a total of $40.7 \%$ children were underweight, $58.9 \%$ were normal and only $0.4 \%$ was over normal. In case of Height for Age (HAZ) $28.9 \%$ children were stunted, $69.9 \%$ were normal and only $1.2 \%$ was over normal. In case of Weight for Height (WHZ) $31.3 \%$ children were wasted, $66.7 \%$ were normal and only $2 \%$ were over $n$ ormal.

Table 14. Relation and impact of hygiene, sanitation and water quality on health status

\begin{tabular}{|l|l|c|c|}
\hline Health status & \multicolumn{1}{|c|}{ Variable } & r & P value \\
\hline \multirow{5}{*}{$\begin{array}{l}\text { Underweight } \\
\text { (WAZ) }\end{array}$} & Condition of the platform of water source & 0.183 & 0.016 \\
\cline { 2 - 4 } & Toilet/latrine being cleaned regularly & 0.215 & 0.003 \\
\cline { 2 - 4 } & Cleanness of toilet floor & 0.138 & 0.014 \\
\cline { 2 - 4 } & Condition of toilet surroundings and entrance to toilet & 0.206 & 0.007 \\
\cline { 2 - 4 } & $\begin{array}{l}\text { Presence of solid waste pit / secondary station near the } \\
\text { house }\end{array}$ & 0.159 & 0.044 \\
\hline \multirow{5}{*}{ Stunting (HAZ) } & Water source for drinking & 0.057 & 0.042 \\
\cline { 2 - 4 } & Condition of the platform of water source & 0.198 & 0.001 \\
\cline { 2 - 4 } & Toilet/latrine being cleaned regularly & 0.226 & 0.001 \\
\cline { 2 - 4 } & $\begin{array}{l}\text { Presence of solid waste pit / secondary station near the } \\
\text { house }\end{array}$ & 0.126 & 0.012 \\
\cline { 2 - 4 } & Frequency of the drain/sewage line cleaning & 0.220 & 0.001 \\
\hline & Water source for drinking & 0.309 & 0.001 \\
\cline { 2 - 4 } & Place of solid waste disposal & 0.065 & 0.001 \\
\cline { 2 - 4 } & Place of household waste water disposal & 0.156 & 0.036 \\
\cline { 2 - 4 } & Presence of dustbin near the slum & 0.196 & 0.000 \\
\cline { 2 - 4 } & Frequency removing waste from the dustbin & 0.222 & 0.000 \\
\hline
\end{tabular}

Table 14 shows that there is a weak but positive correlation among the health status, water quality, environmental sanitation and hygiene practices. The impact of water quality, environmental sanitation and hygiene practices on health status is significant $(p \leq 0.05)$. The results show that water quality, environmental sanitation and hygiene practices could influence the health status of school going children of the slum, while better water quality, environmental sanitation and hygiene practices may lead to healthy child outcome. The results of this study revealed that a total of $26.0 \%$ child respondents were pre-primary student and $74.0 \%$ children respondents were primary student. Maximum households (94.7\%) of the slum use tube-well water for drinking, domestic /household, cleaning purpose. On the other hand only $5.3 \%$ households of the slum use supply water by tap for drinking, domestic /household and cleaning purpose. It was observed that the appearance of maximum household's drinking water was Ironic (yellow color). Most of the household's (56.1\%) drinking water source is within 4-7 meter from toilet. Only $0.4 \%$ drinking water source was greater than ten meter from toilet. Most of the household members were unaware about toilet cleaning, $51.6 \%$ toilets were not cleaned regularly. It was observed that the poor maintenanceoftoilet surroundings and entrance. About 63\% households were preserved their solid waste in open space, only $9.3 \%$ households were thrown in dustbin. Maximum children $(58.1 \%$ ) did not ware sandal while going to latrine, $41.9 \%$ children ware sandal while going to latrine. Majority $(54.5 \%)$ of the children do not cut finger nail regularly, $45.5 \%$ children cut their finger nail regularly. Most of the (63.4\%) household do not use cover for safety of the prepared food, $36.6 \%$ use cover properly for 
safety of the prepared food. It is observed that there was presence of pet/animal/insect in food preparation area in maximum households (78.9). Majorities (63\%) of the drain/sewage lines in the slum were rarely cleaned up and $37 \%$ households of the slum had no drainage facility and $87.4 \%$ households had no dustbin facility near the slum. The child morbidity rate was high. The overall health status of the children shows that $40.7 \%$ children were underweight, $28.9 \%$ children were stunted and $31.3 \%$ children were wasted.The water quality parameters, Environmental sanitation parameters and Hygiene practices parameters are positively correlated with health status. The impact of water quality, environmental sanitation and hygiene practices on health status is significant ( $\mathrm{p} \leq$ $0.05)$.

\section{References}

Awasthi, S. and Bundy, D. 2007. Intestinal nematode infection and anemia in developing countries.British Medical Journal, 334(7603): 1065-1066.

Biswas, S.; Bose, K. and Bisai, S. 2009. Prevalance of Thinness among Rural Bangalee Pre-School Children in Chapra, Nadia District, West Bengal, India. Malaysian Journal of Nutrition, 15:155-164.

Brooker, S.; Clements, A. C. A.; Hotez, P. J.; Hay, S. I. and Tatem, A. J. 2006. The co-distribution of Plasmodium falciparum and hookworm among African schoolchildren. Malar J., 5: 99.

Casapia, M.; Joseph, S. A.; Nunez, C.; Rahme, E. and Gyorkos, T. W. 2006. Parasite risk factors for stunting in grade 5 students in a community of extreme poverty in Peru. Int. J. Parasitol., 36(7): 741-747.

Florence, M. D.; Asbridge, M. and Veugelers, P. J. 2008. Diet quality and academic performance. Journal of School Health, 78(4): 209-215.

Hasan, M. M.; Hoque, M. A.; Hossain, M. A.; Mollah, A. H. and Islam, M. N. 2013. Nutritional status among primary school children of Mymensingh. Mymensingh Med. J., 22(2): 267-274.

\section{Conclusions}

The good hygienic and sanitation knowledge and the practice have been found to be significantly low among the slum dwellers. Majority of the slum people use ironic tube well water for drinking, households and cleaning purposes. The dustbin facility is the most neglected sector in the slums. Besides, Solid waste management and drainage system are totally unsatisfactory in the slum area. The child morbidity rate was high. The water quality, environmental sanitation and hygiene practices have significant impact $(\mathrm{p} \leq 0.05)$ on the health of school going children of these slums.

\section{Acknowledgements}

To Concern Universal Bangladesh for their financial support granted through Master Degree (MS) fellowship.

Moe, C. L and Rheingans, R. D. 2006. "Global challenges in water, sanitation and health". Journal of water and health, :41-57.

Ong, S. G.; Liu, J.; Wong, C. M.; Lam, T. H.; Tam, A. Y. 1991. Studies on the respiratory health of primary school children in urban communities of Hong Kong. Sci. Total Environ., 106(1-2): 121-135.

Pollitt, E. 1999. Early iron deficiency anemia and later mental retardation. Am. J. Clin. Nutr., 69(1): 4-5.

Rema, N. and Vasanthamani, G. 2011. Prevalence of Nutritional and Lifestyle Disorders among School Going Children in Urban and Rural Areas of Coimbatore in Tamil Nadu, India.Indian Journal of Science and Technology, 4(2): 10-16

Singh, V. West, K. P. 2004. Vitamin A deficiency and xerophthalmia among school-aged children in Southeastern Asia. Eur. J. Clin. Nutr., 58(10): 1342-1349.

UNICEF (United Nations International Children's Education Fund 2000. Nutritional assessment in Kenya, Nairobi, Kenya, pp. 1-12. 